\title{
Histological Study of the Effect of Platelet Rich Plasma on Experimentally Induced Skeletal Muscles Injury in Adult Male Albino Rats
} Original

Article

\author{
Shimaa M. Badr, Reda H. Elbakary, Essam M. Laag, Naglaa I. Sarhan, NafisaA.Elbakary
}

Department of Histology, Faculty of Medicine, Tanta University

\begin{abstract}
Background: Muscle injuries are common and may be associated with impaired functional capacity, especially among athletes. Ordinary lines of treatment result in improper healing of the damaged tissue with prolonged time for recovery, so it was essential to try new lines of treatment for these injuries to get advantageous effect on the healing process. One of these new treatments is platelet-rich plasma (PRP), which is used to improve healing of many lesions such as skin and sports injury. Aim of the work: This work was carried out to evaluate the role of platelet rich plasma in healing of experimentally induced skeletal muscle injury in adult male albino rat.

Materials and methods: Thirty adult male albino rats were divided Into: Group I: donor group to obtain PRP from their peripheral blood and muscle specimens from their gasterocnemius muscle. Group II: was exposed to bilateral gastrocnemius muscles injury and was left without treatment. Group III: Bilateral gastrocnemius muscles were injured and immediately treated locally with PRP intramuscularly. Muscle specimens were excised after 1, 7and 21 days from the onset of injury and were processed for light and electron microscopic examination.

Results: PRP treated group demonstrated early formation of many myotubes starting from the 7th day after injury onwards in association with ultrastructural features of activated satellite cells together with restoration of normal histological features of muscle fibers.

Conclusion: local injection of PRP into the injured gastrocnemius muscle resulted in early activation, proliferation and differentiation of satellite cells resulting in earlier and enhanced myogenesis.
\end{abstract}

Received: 25 October 2018, Accepted: 11 January 2019

Key Words: Muscle injury; platelet rich plasma; satellite cells.

Corresponding Author: Reda H. Elbakary, MD, Histology Department, Faculty of Medicine, Tanta Yniversity, Tanta, Egypt, Tel.: +20 1125900338, E-mail: redahassan99@gmail.com

ISSN: 1110-0559, Vol. 42, No. 2

\section{INTRODUCTION}

Musculoskeletal injuries are the most common cause for chronic pain, physical disability and account for the majority of all sport related injuries ${ }^{[1]}$. Regardless of the mechanism of the injury, the healing process progresses through a constant series of overlapping phases resulting in the restoration of anatomic continuity and function ${ }^{[2]}$. These phases are controlled by complex and dynamic molecular mechanisms involving local and systemic factors interacting with many different cell types recruited to the injured site from the surrounding tissues and circulation ${ }^{[3]}$.

Skeletal muscle can regenerate completely and spontaneously in response to minor injuries, such as strain. In contrast, after severe injuries, muscle healing is incomplete, often resulting in the formation of fibrotic tissue that impairs muscle function. Years of research have clarified the time-dependent and interrelated processes that occur after skeletal muscle injures ${ }^{[4]}$.

Widespread use of PRP resides in the fact that it is a simple, efficient and minimally invasive method. PRP used for obtaining a natural concentration of growth factors $[\mathrm{GF}]$ and cytokines from $\alpha$-granules. These granules are the most abundant platelet granules that give the platelets their characteristic purple granular appearance on a typical blood smear ${ }^{[5}$ and 6$]$.

Growth factors in PRP may modulate and regulate the tissue healing process at cellular level. This effect leads to the recruitment, proliferation and differentiation of cells involved in tissue regeneration ${ }^{[7]}$. Based on all these facts, this work aimed to study the effect of platelet rich plasma on the healing of experimentally induced skeletal muscle injury in adult male albino rats.

\section{MATERIALS AND METHODS}

Thirty adult male albino rats aged 6 weeks with average weight 200 grams were used in this work. They were kept in adequate ventilation and room temperature and received a balanced diet with water ad libilum. They were acclimatized for 2 weeks before the experiment. The experiment was approved by the Local Ethics Committee of Faculty of Medicine, Tanta University, Egypt. 


\section{The animals were divided into three groups}

Group I (control group): Included 12 rats that were subdivided into subgroup IA or donor group of 9 rats and subgroup IB of 3 rats that were kept without treatment. The gastrocnemius muscles were obtained from rats of subgroup IB after 1 (subgroup IB1), 7 (subgroup IB7) and 21 (subgroup IB21) days.

Group II (Muscle injury induced group): This group included 9 rats. Under anesthesia their lower limbs were shaved and sterilized with betadine solution. Muscle injury was induced by crushing the gastrocnemius muscle of both lower limbs using blades of the hemostat at level 3 for 2 minutes $^{[8]}$. The rats were left without treatment and were subdivided into three equal subgroups: II A, II B and II C that corresponded respectively to the time of sacrifice ${ }^{[1,721]}$ days after injury induction.

Group III (Muscle injury and PRP treated group): 9 rats were exposed to injury in gastrocnemius muscle of both lower limbs in the same way as group II . Immediately the injured muscles were injected once with $100 \mu \mathrm{l}$ $(0.1 \mathrm{ml})$ of platelet rich plasma by insulin syringe9. Then the rats were divided equally into three subgroups: III A, III B and III C that corresponded respectively to the time of sacrifice ${ }^{[1,7 \text { and 21] }}$ days after injury induction.

\section{Blood collection and preparation of platelet rich plasma}

Preparation of platelet rich plasma was carried out in tissue culture and cytogenetic lab in Histology Department Faculty of Medicine Tanta University.

Blood was collected from donor rats from retro-orbital plexus and occasionally by cardiac puncture after being anesthetized by ether inhalation ${ }^{[9}$ and ${ }^{10]}$. 2.5-3 $\mathrm{ml}$ were collected from each rat by sterile syringe containing $0.3 \mathrm{ml}$ of $3.8 \%$ sodium citrate $(0.5 \mathrm{ml})$ complete blood was taken to count number of platelets in complete blood sample by adding $10 \mu \mathrm{l}$ to $2.5 \mathrm{ml}$ platelet counting solution using hemocytometer. Then citrated blood was centrifuged at $3000 \mathrm{rpm}$ for 7 minutes. The supernatant (containing the buffy coat with platelets and leucocytes) was aspirated by a micropipette, then placed in another sterile tube and centrifuged at $4000 \mathrm{rpm}$ for 5 minutes. After this step the platelets were aggregated in the bottom of the tube in the form of pellet. The supernatant contained plasma poor in platelets so; it was discarded leaving only the pellet and one $\mathrm{ml}$ of the supernatant and resuspended in the tube. $10 \mu \mathrm{l}$ of this suspension was used for manual counting of platelets. It revealed that platelets were nearly 5 times the number in complete blood sample ${ }^{[1]}$. The number of platelets ranged from $1.4 \times 106-2.6 \times 106 / \mu 1$. Activation of PRP by adding $0.1 \mathrm{ml}$ of calcium chloride to each $\mathrm{ml}$ of PRP. After activation it must injected within 10 minutes.

\section{Light microscopic study}

At the appropriate time, the rats were anesthetized with intraperitoneal injection of sodium pentobarbital (35 mg/kg body weight) ${ }^{[12]}$. Gastrocnemius muscles were dissected and the middle parts of the muscle were fixed in $10 \%$ formalin buffered saline. Further routine treatment was carried out with progressive dehydration in alcohol, embedding in paraffin blocks for cutting into $5 \mu \mathrm{m}$ sections to be stained with hematoxylin and eosin ${ }^{[13]}$.

The slides were examined and photographed using Olympus binocular microscope connected to camera.

\section{Morphometric study and Statistical analysis}

The number of central nucleated myofibers in hematoxylin and eosin stained sections was evaluated. Using the image $\mathrm{J}$ software (V 1.48), the number of centrally nucleated myofibers in HE. stained sections was counted in 10 non-overlapping randomly chosen fields for each slide prepared. The magnification power of $(\times 10)$ was used). The data were analyzed by Kruskal-Wallis test (Non parametric ANOVA test). Differences were regarded as significant if $P>0.05$.

Electron microscopic study: $1 \mathrm{~mm} 3$ muscle specimens were immediately immersed in 3\% phosphate buffered glutaraldehyde for 4 hours with $\mathrm{pH}$ 7.2. The samples were then processed as routine EM preparation ${ }^{[14]}$. Ultrathin sections were examined by a JEOL electron microscope at $80 \mathrm{kV}$ in Faculty of Medicine, Tanta University, Egypt.

\section{RESULTS}

\section{I- Light microscopic results}

1- Control group (Subgroup IB): light microscopic examination of $\mathrm{HE}$ stained sections of gastrocnemius muscle of subgroup IB at intervals 1, 7 and 21 days showed the normal histological structure of the skeletal muscle. In transverse section, the skeletal muscle was formed of bundles of skeletal muscle fibers separated by connective tissue (perimysium). The individual muscle fibers were separated by connective tissue (endomysium). Individual muscle fibers appeared polygonal in shape with peripheral nuclei. In longitudinal section, the skeletal muscle fibers appeared long, parallel, cylindrical and multinucleated with peripherally located pale nuclei just beneath the sarcolemma, with their long axis parallel to the long axis of muscle fibers. Besides skeletal muscle nuclei, other dense flattened nuclei were present most probably representing satellite cell nuclei. The sarcoplasm appeared acidophilic with transverse striations (Figure 1).

Group II (Muscle injury induced group): depicted severe widespread histological alterations in all skeletal muscle elements and its surrounding connective tissue (Figure 2).

Subgroup IIA (At day 1 after injury): showed loss of normal architecture of skeletal muscle. Some areas of sarcoplasm showed fragmentation or complete loss. Inflammatory cellular infiltration and widened spaces between individual muscle fibers were observed.

Subgroup IIB (At day 7 after injury): showed few muscle fibers which appeared with basophilic sarcoplasm 
and row of linear central nuclei forming few myotubes. Loss of continuity of muscle fibers was also observed with sarcoplasmic shadows and congested blood vessels. Wide spacing of muscle fibers was detected. Splitting of muscle fibers with internalization of myonuclei was observed. Widening of endomysium and increased perimysial connective tissue were also detected.

Subgroup IIC (At day 21 after injury): displayed prominent variable sized muscle fibers with internalization of their nuclei and widening of endomysium.

Group III (muscle injury and PRP treated group): depicted appearance of many myotubes and regression of the inflammatory reaction starting from the $7^{\text {th }}$ day onward (Figure 3).

Subgroup IIIA (at day 1 after injury): showed nearly the same findings observed in the same period within the previous group. These were in the form of splitting of some muscle fibers, fragmentation of sarcoplasm. Wide spacing of muscle fibers with inflammatory cellular infiltration and hemorrhage were also observed.

Subgroup IIIB (at day 7 after injury): revealed formation of regenerated myotubes with basophilic sarcoplasm and chain of central pale nuclei. Similarly, transverse sections revealed also many basophilic newly formed small muscle fibers with central nuclei while, some fibers showed vacuolations. Widening of perimysial C.T. was clearly demonstrated.

Subgroup IIIC (at day 21 after injury): displayed well evidenced restitution of the normal general architecture of their muscles to be more or less similar to control muscle fibers. They appeared long, cylindrical, parallel, multinucleated, with acidophilic sarcoplasm and transverse striations. Their nuclei were peripheral, pale, and subsarcolemmal in position.

\section{II- Electron microscopic results}

\section{1-Subgroup IB [control]}

Examination of longitudinal ultrathin sections of gastrocnemius muscle of at periods 1,7 and 21 days revealed the normal ultrastructural features of skeletal muscle fibers. Myofibrils had regular arrangement of alternating light (I) and dark (A) bands parallel to the long axis of the myofiber. Both A and I bands were bisected by narrow regions of contrasting density. Each $\mathrm{A}$ band was bisected by a paler $\mathrm{H}$ zone and a dark $\mathrm{M}$ line within it. Each I band was bisected by a dark $\mathrm{Z}$ line. Regular sarcomeres appeared between successive $Z$ lines. Under the sarcolemma, an oval regular euchromatic nucleus with prominent nucleolus was present. In-between myofibrils, small paired mitochondria and glycogen granules were present around $\mathrm{Z}$ lines. Subsarcolemmal mitochondria were also present. Satellite cells appeared separated from the muscle fiber by its own plasma membrane with characteristic oval, heterochromatic nucleus surrounded by cytoplasm rich in ribosomes (Figure 4).

\section{Group II (Muscle injury induced group)}

Subgroup IIA after 1 day of injury showed focal damage of skeletal muscle in the form of sarcoplasmic loss, disruption, fragmentation and disorganization of their myofibrils in association with irregular disrupted or detached sarcolemma (Figure 5A).

Subgroup IIB after 7 days: This group revealed persistence of some changes which were observed in the previous subgroup IIA like irregular corrugated sarcolemma and focal disrupted arrangement of myofibrils. The nucleus appeared irregularly cleaved with corrugated nuclear membrane. Perinuclear focal areas of cytoplasmic vacuolations were obviously seen (Figure 5B).

Subgroup IIC After 21 days depicted the same changes which were observed in previous periods as disrupted myofibrils together with perinuclear area of sarcoplasmic loss (Figure 5C).

Group III (Muscle injury and PRP treated group): Subgroup IIIA After 1 day showed no difference when compared with the same period in the previous group. Irregularly disrupted sarcolemma and disrupted myofibrils with disorganized sarcomeres were observed. Internalization of muscle nucleus in-between myofibrils was observed in addition to electron dense bodies within degenerated cytoplasm. (Figure 6A). Subgroup IIIB after 7 days revealed extensive accumulation of mitochondria and glycogen granules under the sarcolemma and in-between myofibrils. Activated satellite cells were prominent outside the sarcolemma with its characteristic ribosome rich cytoplasm and elongated cytoplasmic processes. It was present in-between two muscle cells that contained fused large mitochondria and subsarcolemmal mitochondria (Figure 6B and C). Subgroup IIIC after 21days revealed results more or less similar to the control group. This was in the form of nearly normal muscle fibers with regular sarcomeres. Subsarcolemmal oval euchromatic myonucleus with thin condensed peripheral chromatin and prominent nucleolus was observed. Satellite cells with its cytoplasm rich in ribosomes outside the sarcolemma were seen (Figure 7).

\section{Statistical Results}

(Table 1) and (Bar chart 1) show significant increase in the mean number of centrally nucleated myofibers in PRP treated subgroup (IIIA) on the 1st day when compared to control $(P$-value $<0.05)$ but insignificant difference when compared to subgroup (IIA) with ( $P$-value $>0.05$ for both).

Interestingly, group III depicted highly significant increase in the mean number of centrally nucleated myofibers in subgroup (IIIB) $(P$-value $=0.0004)$ on the $7^{\text {th }}$ day when compared to other groups on the same day.

(Table 1) and (Bar chart 1) show also significant increase in the mean number of centrally nucleated myofibers in non-treated subgroup IIC on 21th day when compared to the same group on the $1^{\text {st }}(P$-value $<0.05)$ and $7^{\text {th }}$ days $(P$-value $<0.05)$, control $(P$-value $<0.01)$, and subgroup IIIC $(P$-value $=0.0017)$. 




Fig. 1: H E stained sections of the gastrocnemius muscle of a control rat. A: shows acidophilic polygonal muscle fibers [curved arrows] in their transverse section with peripheral nuclei [arrows]. B: shows longitudinal section of these muscle fibers with acidophilic sarcoplasm and transverse striations [arrows]. Peripheral subsarcolemmal oval nuclei [arrow head] are present in addition to flattened dark nuclei of satellite cells which are interposed between plasma membrane of the muscle fiber and its external lamina [curved arrows]. [HE, A, x, 400 B, x1000]



Fig. 2: H E stained sections of the gastrocnemius muscle of group II: A: subgroup IIA: shows fragmentation of sarcoplasm [arrows] alternating with sarcoplasmic loss [bifid arrows]. Wide spacing between muscle fibers [stars] with inflammatory cellular infiltration [arrow head]. B: subgroup IIB: shows few basophilic muscle fibers [thin arrow] with linear central nuclei [arrow head] forming few myotubes. Many muscle fibers appear with sarcoplasmic shadows [curved arrows] and congested blood vessels [thick arrow]. Wide spacing of muscle fibers [stars] is also observed. C: subgroup IIB: shows splitting of sarcoplasm with internalization of nuclei [curved arrow] in addition to widening of endomysium [stars] and increase in perimysial connective tissue [arrows]. D: subgroup IIC: exhibits wide spacing of variable sized muscle fibers [stars] with internal nuclei [arrow heads]. [HE, x400] 


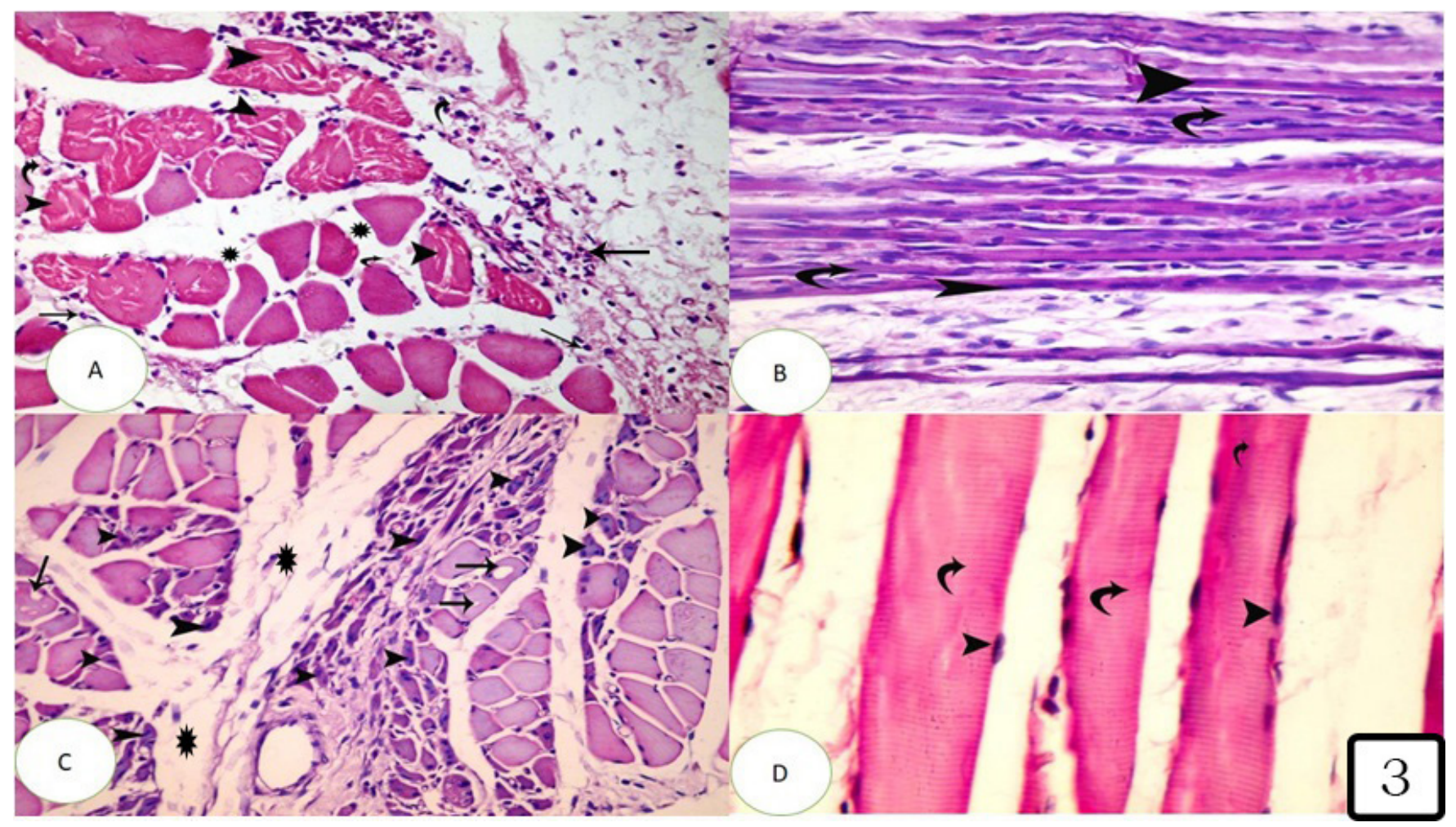

Fig. 3: H E stained sections of the gastrocnemius muscle of group III: A: subgroup IIIA: transverse section in the gastrocnemius muscle shows wide spacing of muscle fibers [stars] with fragmentation of the sarcoplasm [arrow heads] in addition to cellular infiltration [arrows] and hemorrhage [curved arrows]. B subgroup IIIB reveals many newly formed basophilic myotubes [curved arrows] with row of central pale nuclei [arrow heads].C: subgroup IIIB: shows many newly formed small myofibers with basophilic sarcoplasm and central nuclei [arrow heads]. Some fibers show vacuolations [arrows]. Notice: wide spacing between muscle fibers [stars]. D: subgroup IIIC: shows long parallel muscle fibers with acidophilic sarcoplasm, transverse striations [curved arrows], with peripheral pale myonuclei [arrow heads] to be more or less similar to control. [HE, A, x400, B, x400, C, x200, D, x1000]
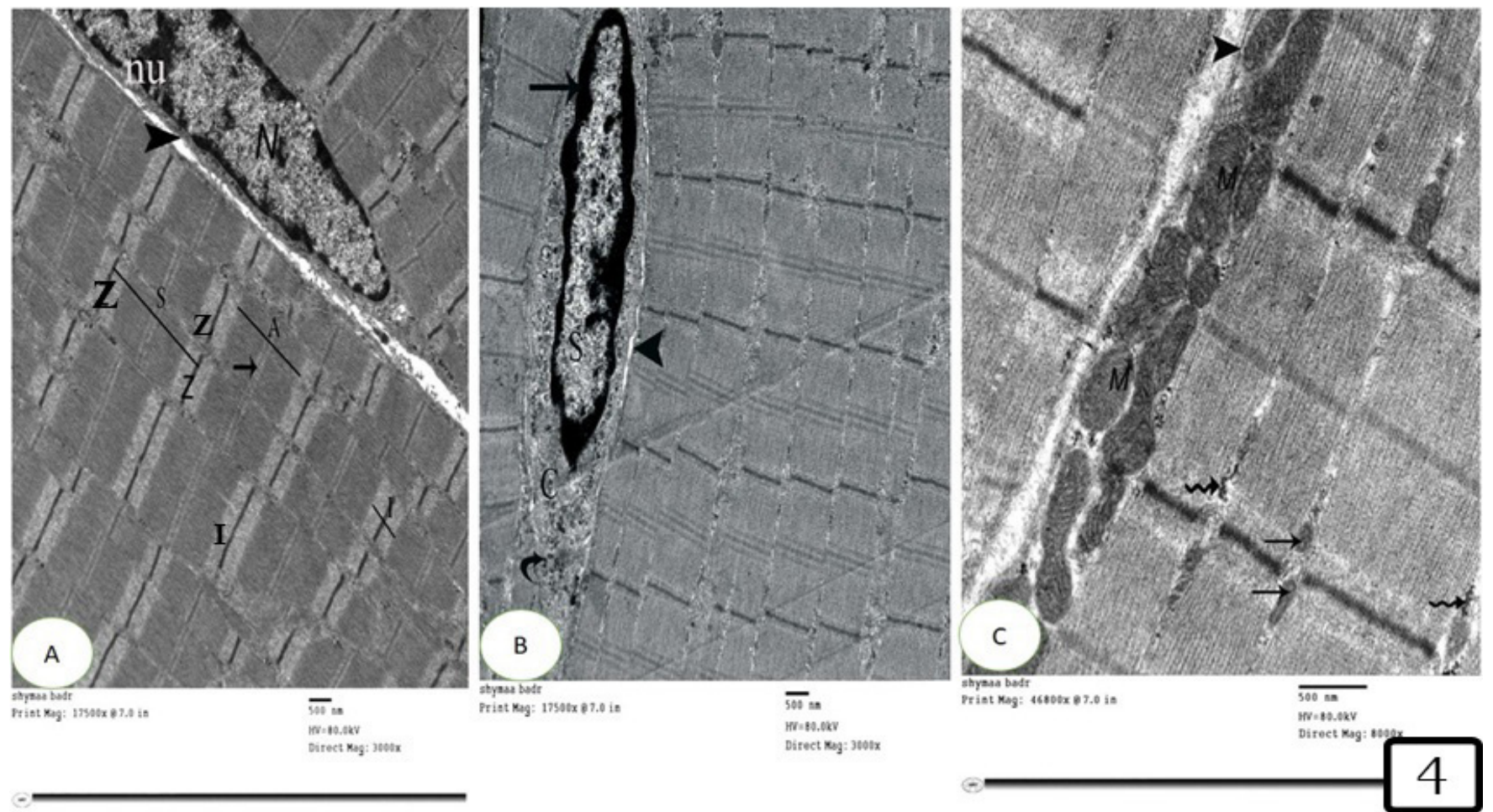

Fig. 4: An electron micrograph of a longitudinal ultrathin section of gastrocnemius muscle of control group IB: A shows normal banding pattern of the myofibrils with alternating light [I] and dark [A] bands. Z lines [Z] and M lines [arrow] appear in the middle of I and A bands. Sarcomeres [S] are observed in-between two successive $\mathrm{Z}$ lines. The muscle nucleus $[\mathrm{N}$ ] with prominent nucleolus [nu] appears oval and elongated under the sarcolemma [arrow head]. B displays satellite cell [S] outside the sarcolemma [arrow head] with its nucleus having peripheral condensed chromatin [arrow] surrounded by cytoplasm [C] rich in ribosomes [curved arrow]. C reveals subsarcolemmal mitochondria [arrow head] [M] and interfibrillar mitochondria [arrows]. Glycogen granules appear in- between myofibrils [tortuous arrows]. [Mic.mag. A Bx3000, C x8000] 




Fig. 5: an electron micrograph of a section of gastrocnemius muscle of group II. A. subgroup IIA: shows detached sarcolemma [arrow], fragmented myofibrils [arrow heads] alternating with areas of sarcoplasmic loss [stars] and irregularly arranged myofibrils [curved arrows]. B: subgroup IIB presents irregularly arranged myofibrils and disrupted sarcolemma [arrow] and, disorganized sarcomeres [curved arrow]. Abnormal irregular nucleus [N] with corrugated nuclear membrane [arrow head] is also present. Perinuclear focal areas of cytoplasmic vacuolations were seen. C: subgroup IIC: shows disrupted myofibrils [arrows] and cytoplasmic loss [curved arrows] around muscle nucleus [N]. [Mic.mag. Ax5000, BC x3000]



Direet Koy: soutx



Fig. 6: an electron micrograph of a section of gastrocnemius muscle of group III. A: subgroup IIIA: shows disrupted myofibrils with irregular sarcolemm [arrow], internalization of muscle nucleus [N] in-between myofibrils and electron dense bodies within degenerated cytoplasm [arrow heads]. B: subgroup IIIB: shows more regular arrangement of myofibrils, excessive accumulation of mitochondria under the sarcolemma [arrow heads]. Megamitochondria are also present in-between myofibrils [arrow].C: subgroup IIIB reveals satellite cell [S] in-between muscle fibers with elongated cytoplasmic process [bifid arrows] and cytoplasm rich in ribosomes [arrows]. Fused large mitochondria [curved arrows] and subsarcolemmal mitochondria [M] are also present. [Mic.mag. $\mathrm{Ax} 5000, \mathrm{BC} \times 3000]$ 



Fig. 7: an electron micrograph of a section of gastrocnemius muscle of subgroup IIIC A: shows nearly normal muscle fibers with sarcomeres between successive Z line. Subsarcolemmal euchromatic oval muscle nucleus [N] with smooth outline and prominent nucleolus [arrow head]. B: exhibits nearly normal muscle fibers with normal banding pattern with dark A bands, light I bands and regular sarcomeres between successive Z lines. Part of satellite cell [S] outside the sarcolemma [curved arrow] with its cytoplasm [arrow head] rich in ribosomes [arrow] is also present [Mic.mag. A x3000, B x5000].

Table 1: Mean \pm SD of number of centrally nucleated myofibers in the different studied groups








Bar chart 1: Mean \pm SD of number of centrally nucleated myofibers in the different studied groups

\section{DISCUSSION}

In vitro studies and animal research have suggested that PRP may have benefits associated with increased release of cytokines and growth factors resulting from supraphysiological concentrations of platelets. These factors, when introduced to the area of injury, are expected to increase recruitment, proliferation and differentiation of cells involved in tissue repair ${ }^{[4,15}$ and 16$]$.

Growth factors [GF] released in damaged tissue bind to receptors present in the mesenchymal and epithelial cell membranes. These factors activate the transcription of proteins that control the cell cycle, inducing a series of protein phosphorylation processes inside cells. This basic mechanism stimulates mitotic division and, consequently, the cellular proliferation and synthesis of extracellular matrix and collagen at the injury location ${ }^{[17}$ and 18$]$.

The results obtained from group II of induced muscle injury, showed muscle degeneration, fragmentation and inflammatory infiltrate at day 1 after injury. These data were in agreement with other researches ${ }^{[19}$ and 20]. Who reported capillary rupture and bleeding leading to the first phase of degeneration/inflammation. This phase is characterized by rupture of myofibrils and their necrosis. These changes were explained by some authors. They stated that the early phase of muscle injury is usually accompanied by the activation of inflammatory cells residing within the muscle, which release pro and anti-inflammatory cytokines such as TNF- $\alpha$, IL-6, IL-10, IL-1b and TGF- $\beta 1$. These cytokines play an important role in cell proliferation, chemotaxis and cell differentiation. Also, skeletal muscle produces IL-6 in response to the injury which acts both as a factor for the proteolysis of damaged myofibers and as a signal for satellite cell proliferation ${ }^{[222]}$.

Muscle specimens obtained from non-treated Group II after 7 and 21 days depicted a combination of muscle degeneration and regeneration. Interestingly, it was documented that fourteen days after injury, the injured site exhibited an intense mononucleated inflammatory infiltrate, among granulation tissue containing myocyte fragments. The presence of basophilic cells over the area of discontinuous muscular architecture was noticed with augmented nucleus cytoplasm ratio and evident nucleolus that corresponds to immature cells. Moreover, the reestablishment of myocyte rows seemed to be formed from myoblasts fused with degenerating myocytes, forming multinucleated structures in the corresponding region emphasizing a repairing process that is dependent on preexisting myocytes fused with myoblasts ${ }^{[23]}$.

Another explanation was presented by many authors ${ }^{[2425]}$ who reported that satellite cells are activated and produce myoblasts, which eventually fuse with other myoblasts resulting in mature and multinucleated myofibers. Mosca Rodeo $^{[16]}$ also verified that myogenic precursor cells are derived from muscle satellite cells that rapidly proliferate and have significant regenerative capacity. As they differentiate into myofibers and fuse together, remodeling and reorganization begins.

In the present study, subgroup IIIA [PRP treated group at day 1 after injury] also showed swelling of muscle fibers, inflammatory cellular infiltration in-between muscle fibers, Fragmentation of sarcoplasm and widening of endomysium. These data were in agreement with other researchers ${ }^{[321]}$ who demonstrated that PRP treatment magnifies the early physiological inflammatory response following muscle injury with a concomitant modification of the pattern of cellular recruitment as well as the enhanced expression of myogenic factors to promote myogenesis.

Another explanation was mentioned in previous works ${ }^{[26,2728]}$. They reported that leucocytes in PRP may mimic the initial phase of inflammation in which a high number of neutrophils infiltrate the injured site; the interactions of neutrophils with platelets can induce a hyperactive leukotactic response of circulating neutrophils towards the injury site.

In this study, muscle specimens obtained from platelet rich plasma treated group at day 7 revealed prominent features of myogenesis as evidenced by appearance of many myotubes with basophilic sarcoplasm and row of central pale nuclei. At day 21, long, cylindrical, parallel, multinucleated muscle fibers with acidophilic sarcoplasm and transverse striations appeared. These changes were in agreement with other researches. They stated that, following the inflammatory response, activation of normally quiescent satellite cells [SCs] is an integral part of the repair process. This process is characterized by an increased transcription of the myogenic regulatory factors MyoD1, PAX7, Myf5, myogenin and Mrf4. They also observed that at days 2 and 5, early stages of muscle regeneration, both mRNA transcripts for MyoD1, Myf5, PAX7, myogenin and an abundant number of MyoD1and Pax7-positive cells were present in all experimental groups after muscle injury. This response was clearly more elevated in the muscle treated with PRP, with the exception of Mrf4, mRNA and myogenin protein levels $\mathrm{s}^{[0,2129]}$.

Also it was reported that several growth factors abundant in PRP like hepatocyte growth factor [HGF] is the primary component of crushed muscle extract, and it is currently the most probable candidate for initiating regeneration by satellite cell activation. They also reported that both IGF-I and -II increase following muscle injury and promote 
myoblast proliferation and myofiber differentiation as well as enhancing muscle cell survival and hypertrophy under tissue-specific circumstances ${ }^{[28,3031]}$.

In this study, morphometric and statistical results confirmed the effect of PRP on early and enhanced regeneration of muscle injury. Group III (PRP treated) showed significant increase in the mean number of centrally nucleated myofibers as compared to group II (non-treated group) and control group. This significant difference was prominent on day 7 in PRP treated group (group III).

This was in agreement with other authors ${ }^{[15]}$ who observed that PRP treated tibialis anterior had even higher number of central nucleated myofibers than injured tibialis anterior with no treatment. Moreover, some works ${ }^{[3233]}$ previously mentioned that centrally nucleated fibers are widely accepted as a marker of muscle regeneration.

Electron microscopic results of this study co firmed the light microscopic ones. As, non-treated group II showed signs of degeneration even at day 21 combined with focal regeneration, while PRP treated group III showed prominent regeneration starting from the $7^{\text {th }}$ day and generalized regeneration at day 21 .

In the present study, both group II (untreated group) and group III (PRP treated group) at day 1 showed nearly the same findings. The most prominent features were: alteration of sarcolemma, myofibrils, mitochondria, and muscle nuclei. The same findings were still observed in the same group II (non-treated) at days 1, 7 and 21 in addition to focal areas of regularly arranged myofibrils with normal banding pattern.,

Irregular disrupted sarcolemma seen in muscle specimen of group II was explained by other work $^{[34]}$ as necrosis secondary to muscular dystrophies. It was documented that changes in the dystrophin-glycoprotein complex and reduced expression of $\alpha$-sarcoglycan immediately after eccentric contraction may destabilize the sarcolemma leading to modifications of membrane permeability. The decrease in the level of $\alpha$-sarcoglycan may also regulate the intracellular calcium concentration and therefore, resulting in intracellular $(\mathrm{Ca} 2+)$ overloading in muscle fibers that in turn may activate $(\mathrm{Ca} 2+)$ dependent proteolytic pathways and affect cell membrane integrity ${ }^{[35]}$.

Focal damage of muscle fibers in the form of disrupted myofibrils with areas of complete or partial sarcoplasmic loss with electron dense bodies, irregular arrangement of myofibrils and disorganized sarcomeres were observed in both PRP treated and non-treated groups. The same findings were observed ${ }^{[36]}$ in damaged muscle after one day from injury. This could be attributed to disruption of the intermediate filaments(desmin)by an increase in $(\mathrm{Ca} 2+)$ that in turn activates $(\mathrm{Ca} 2+)$ dependent proteases such as calpain leading to inability of the disrupted myofibrillar apparatus to develop normal tension ${ }^{[35]}$. Also, some authors stated that myofibrillar structure is disorganized in degenerating and regenerating fibers ${ }^{[34]}$.
In this study, abnormal myonuclei also were prominent in group II [non-treated] either in architecture or in acquiring abnormal position in-between myofibrils at day1 to be surrounded by area of cytoplasmic loss at day 21 within the same group. This was explained as, during regeneration, various cellular organelles become activated and involved in repair. It was reported that peri/ intranuclear vacuoles was one of the common characteristic pathological features in nuclear envelopathies ${ }^{[37]}$. They hypothesized that these could be secondary changes to the altered nuclear envelope ${ }^{[38]}$.

Extensive accumulation of mitochondria under the sarcolemma and in-between myofibrils was observed in muscle of PRP treated group III at day $7^{[39]}$. It could mention that prominent subsarcolemmal accumulation of mitochondria and its proliferation were attributed to an attempt of the cell to compensate for the respiratory chain defect. The observation of large fused mitochondria was explained as ${ }^{[40]}$ the cells are protected from mitochondrial dysfunction by complementation of DNA products in fused mitochondria. Thus they could compensate for defects induced by various kinds of damage.

Interestingly, one of the prominent features in this study was the appearance of ultrastructural features of activated satellite cells. Activated satellite cells appeared with its cytoplasm outside the sarcolemma having plentiful free ribosomes in group II (non-treated) at day 21 and in PRP treated group III, starting from the $7^{\text {th }}$ day onwards.

Also activated satellite cells were observed with increased volume together with ribosomes in cytoplasm ${ }^{[41]}$. This finding was in agreement with other research ${ }^{[42]}$. Remarkably, it was reported that PRP produces a more pronounced increase of myogenic precursor cells together with an expansion of the myogenic cell pool necessary for myofiber formation $^{[30]}$.

From the previous discussion, it was observed that PRP had a significant effect on enhancement of muscle regeneration after injury. This effect was obtained by promoting proliferation, activation, differentiation of satellite cells and restoration of normal structure of muscle fibers. This effect was observed early and was generalized in PRP treated group as compared to non-treated group. The same finding was documented in previous work, ${ }^{[43]}$ who stated that full recovery of functional capabilities was restored in half the expected time, and images showed full regenerated muscle tissue after PRP treatment. According to Hamilton and Best, ${ }^{[44]}$, Platelets are rich in growth factors that can stimulate myogenesis and mitigate inflammation.

\section{CONCLUSION}

Treatment with PRP resulted in early and enhanced regeneration of skeletal muscle injury.

\section{CONFLICT OF INTEREST}

The authors report no conflict of interest. 


\section{REFERENCES}

1. Beiner JM, and Jokl P. Muscle contusion injury and myositis ossificans traumatica. Clin OrthopRelat Res 2002; 403 Suppl: S110-9.

2. Tidball JG. Mechanisms of muscle injury, repair, and regeneration. Compr Physiol. $2011 ; 1(4): 2029-62$.

3. Borrione P, Grasso L, Chierto E, Geuna S, Racca $\mathrm{S}$, Abbadessa $\mathrm{G}$, et al. Experimental model for the study of the effects of platelet-rich plasma on the early phases of muscle healing. Blood Transfus 2014; 12(1): s221-8.

4. Huard J, Li Y, and Fu FH. Muscle injuries and repair: current trends in research. J Bone Joint Surg Am 2002;84-A(5):822-32.

5. Maynard DM, Heijnen HF, Horne MK, White JG, and Gahl WA. Proteomic analysis of platelet alpha-granules using mass spectrometry. J Thromb Haemost 2007;5:1945-55.

6. Ozgürtaş T, Utku B, and Yilidiz C. Plateletrich plasma. In: Musculoskeletal research and basic science, 1st edition. By Korkusuz F. Springer International Publishing Switzerland; 2016. Pp.283-8.

7. Stratos I, Madry H, Rotter R, Weimer A, Graff J, Cucchiarini M, Mittlmeier T, Vollmar B.Fibroblast growth factor-2-overexpressing myoblasts encapsulated in alginate spheres increase proliferation, reduce apoptosis, induce adipogenesis, and enhance regeneration following skeletal muscle injury in rats.Tissue Eng Part A. 2011;17(21-22):2867-77.

8. Ioannis Stratos, Zhengdong Li, Robert Rotter, Philipp Herlyn, Thomas Mittlmeier, and Brigitte Vollmar. Inhibition of caspase mediated apoptosis restores muscle function after crush injury in rat skeletal muscle. Apoptosis. 2012 ; 17(3): 269-277.

9. Quarteiro ML, Tognini JRF, Flores de Oliveira EL, and Silveira I. The effect of platelet-rich plasma on the repair of muscle injuries in rats. Rev Bras Ortop 2015; 50(5): 586-95.

10. Kim DH, Je YJ, Kim CD, Lee YH, Seo YJ, Lee $\mathrm{JH}$, et al. Can platelet rich plasma be used for skin rejuvenation. Evaluation of effects of platelet rich plasma on human dermal fibroblast. Ann Dermatol 2011, 23: 424-31.

11. Mary Lou, T. Clinical hematology - theory and procedures, 5th edition. Lippincott Williams Wilkins, Philadelphia, PA; 2011. pp. 320-

12. Gaertner, D.J., Hallman, T.M., Hankenson, F.C., Batchelder, M.A.,. Anesthesia and analgesia for laboratory rodents. In: Fish, R.E., Danneman, P.J., Brown, M., Karas, A.Z. (Eds.), Anesthesia and Analgesia in Laboratory Animals. , 2nd ed. Academic Press, London (UK),2008, pp. 239-297.

13. Gamble M. The hematoxylins and eosin. In: Bancroft JD, Gamble M, editors. Theory and practice of histological techniques.6th ed. London: Churchill Livingstone.2008. p 121-135.

14. Woods A, and Stirling J. Electron microscope. In: Theory and practice of histological techniques. By: Bancroft JD and Gamble M (eds), 6th edition. ChuchillLivengstone; London; Sydney; New York; Toronto; 2008. pp. 601-40.

15. Hammond JW, Hinton RY, Curl LA, Muriel JM, and Lovering RM. Use of autologous platelet-rich plasma to treat muscle strain injuries. Am J Sports Med 2009; 37(6): 1135-42.

16. Mosca MJ, and Rodeo SA.Platelet-rich plasma for muscle injuries: game over or time out?Curr Rev Musculoskelet Med 2015; 8(2):145-53.

17. Marx, RE: Platelet -rich plasma: evidence to support its use. JOral Maxillofac Surg, 2004;62(4):489-96.

18. Cole BJ, Seroyer ST, Filardo G, Bajaj S, and Fortier LA: Platelet -rich plasma where we are now and where we are going? Sports health Multi Approch 2010. 2(3):203-10.

19. FalcaiMJ, Monte-Raso VV, Okubo R, Zamarioli A, Carvalho LC, and Shimano AC. Biomechanical and histological analysis of the gastrocnemius in rats subjected to muscle Injury and treatment with low-level laser therapy. Rev Bras Ortop 2010; 45(4):444-8.

20. Harmon KG. Muscle injuries and PRP: what does the science say? Br J Sports Med 2010; 44:616-7.

21. Dimauro I, Grasso L, Fittipaldi S, Fantini C, Mercatelli N, Racca S, et al. Platelet-rich plasma and skeletal muscle healing: a molecular analysis of the early phases of the regeneration process in an experimental animal model. PLoS One 2014; 9(7): e102993. doi:10.1371/journal.pone.0102993.

22. Takhtfooladi MA, Shahzamani M, Takhtfooladi HA, Moayer F, and AllahverdiA.Effects of light-emitting diode (LED) therapy on skeletal muscle ischemia reperfusion in rats. Lasers Med Sci 2015; 30(1):311-6.

23. Ferreira Filho CM, Silva AM, Sudo RT, Takiya CM, and Machado JC. Laceration in rat gastrocnemius. Following-up muscle repairing by ultrasound biomicroscopy (in vivo), contractility test (ex vivo) and histopathology. Acta Cir Bras 2015; 30(1):13-23. 
24. Li Y, and Huard J. Differentiation of musclederived cells into myofibroblasts in injured skeletal muscle. Am J Pathol 2002; 161:895-907.

25. Prisk V, and Huard J. Muscle injuries and repair: the role of prostaglandins and inflammation. HistolHistopathol 2003; 18:1243-56.

26. Tidball JG. Inflammatory processes in muscle injury and repair. Am J PhysiolRegulIntegr Comp Physiol 2005; 288(2):R345-53.

27. Tiidus PM. Skeletal muscle damage and repair: classic paradigms and recent developments. J Musculoskeletal Pain 2010; 18(4):396-402.

28. Andia I, Mikel Sanchez M, and Maffulli N. Platelet rich plasma therapies for sports muscle injuries: any evidence behind clinical practice? Expert Opin Biol Ther 2011; 11(4):509-18.

29. Parise G, O'Reilly CE, and Rudnicki MA. Molecular regulation of myogenic progenitor populations. Appl PhysiolNutrMetab 2006; 31: 773-81.

30. Christov C, Chrétien F, Abou-Khalil R, Bassez G, Vallet G, Authier FJ, et al. Muscle satellite cells and endothelial cells: Close neighbors and privileged partners. Mol Biol Cell 2007; 18(4):1397-409.

31. Ten Broek RW, Grefte S, and Von den Hoff JW. Regulatory factors and cell populations involved in skeletal muscle regeneration. J Cell Physiol 2010; 224:7-16.

32. Charge SB, and Rudnicki MA. Cellular and molecular regulation of muscle regeneration. Physiol Rev 2004; 84:209-38.

33. Järvinen TA, Järvinen TL, Kääriäinen M, Kalimo $\mathrm{H}$, and Järvinen $\mathrm{M}$. Muscle injuries: biology and treatment. Am J Sports Med 2005; 33 (5): 745 - 64.

34. Curtis E, and SewryC.Electron microscopy in skeletal muscle pathologyIn: Diagnostic electron microscopy: A practical guide to interpretation and technique. By: Stirling JW, Curry A, Eyden B (eds), 1st edition. John Wiley Sons, Ltd; 2013. pp. 89-115.
35. Magaudda L, Di Mauro D, Trimarchi F, and AnastasiG.Effects of physical exercise on skeletal muscle fiber: Ultrastructural and molecular aspects. Basic Appl Myol 2004; 14(1): 17-21.

36. Fisher BD, and Rathgaber M. An overview of muscle regeneration following acute injury. J Phys Ther Sci 2006; 18: 57-66.

37. Tero AH Järvinen, Markku Järvinen, and Hannu Kalimo . Regeneration of injured skeletal muscle after the injury. Muscles Ligaments Tendons J. 2013; 3(4): 337-345.

38. Park YE, Hayashi YK, Goto K, Komaki H, Hayashi $\mathrm{Y}$, Inuzuka $\mathrm{T}$, et al. Nuclear changes in skeletal muscle extend to satellite cells in autosomal dominant Emery-Dreifuss muscular dystrophy/limb-girdle muscular dystrophy $1 \mathrm{~B}$. NeuromusculDisord 2009; 19(1):29-36.

39. Cullen MJ, Johnson MA, and Mastalgia FL. Pathological reactions of skeletal muscle. In:Skeletal muscle pathology. By: Mastalgia FL, Walton I (eds), 2nd edition. Churchill Livingstone, Edinburgh, London, New York, Philadelphia, Sanfrancisco, Sydney, Toronto; 2001. Pp. 123-84.

40. Wakabayashi T. Megamitochondria formation physiology and pathology. J Cell Mol Med 2002; 6(4):497-538.

41. Hang Yin, Feodor Price, and Michael A. Rudnicki Satellite Cells and the Muscle Stem Cell Niche. Physiol Rev. 2013 ; 93(1): 23-67.

42. Gregory MA, and Mars M.Mobilisation of satellite cells following ischaemia and reperfusion in primate skeletal muscle. Sports medicine 2004; 16(1):17-24

43. Sánchez M, Anitua E, Orive G, Mujika I, and Andia I. Platelet-rich therapies in the treatment of orthopaedic sport injuries. Sports Med 2009; 39 (5):345-54.

44. Hamilton BH, and Best TM. Platelet-enriched plasma and muscle strain injuries: challenges imposed by the burden of proof. Clin J Sports Med $2011 ; 21: 31-6$ 
الملخص العربى

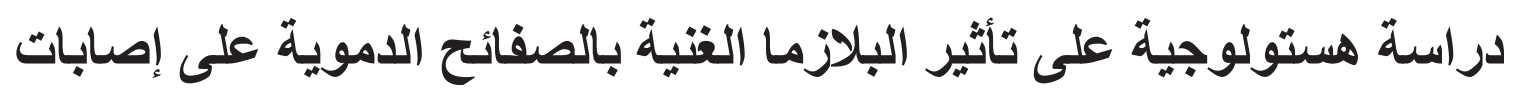

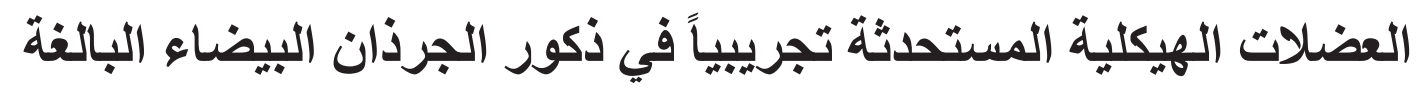

شيماء محمود بلر، رضا حسن البقرى، عصام محمود لعج، نجلاء ابراهيم سرحان، نفيسة عبد الرحيم البقرى قسم الهنتولوجى كلية الطب جامعة طنطا

تعتبر اصابات العضلات الهيكلية من الاصابات الثائعة وقد تتر افق مع ضعف القدر ات الوظيفية, وخاصة بين الرياضيين, العلاجات العادية ينتج عنها شفاء غير متكامل فى وقت طويل. لذلك كان من الضروري تجربة طرق جديدة لعلاج هذه الإصابات للحصول على تأثنير مفيد على عملية الثفاء. واحدة من هذه العلاجات الجديدة هي البلازما الغنية بالصفائح الدموية التي تستخدم لتحسين الثفاء من العديد من اصابات الجلد و الإصـابات الرياضية. الهدف من البحث: أجرى هذا البحث لتقييم دور البلازما الغنية بالصفائح الدموية فى الثفاء من اصابة العضلات الهيكلية المستحدثة تجريبيا فى ذكور الجرذان البيضاء البالغة. المواد وطرق البحث: تم تقسيم ثناثثن من ذكور الجرذان البيضاء إلى المجمو عة الأولى: مجمو عة لتجميع عينات الدم للحصول على البلازما الغنية بالصفائح الدموية وعينات العضلات من عضلة السمانة. المجموعة الثانية: تعرضت لإصابة في عضلة السمانة بكلا الطرفين و تركت دون علاج. المجموعة الثالثة: نم أصابة عضلة السمانة بها فى كلا الطرفين و علاجهم فورا بالحقن الموضعى بالبلازما الغنية بالصفائح الدموية. تم استنئصال عينات العضلات بعد 1 و 7


النتائج: أظهرت مجموعة المعالجة بالبلازما الغنية بالصفائح الدموية في وقت مبكر تشكيل العديد من الالباف مركزية النو اة بدءا من اليوم السابع بعد الإصابة فصاعدا. و الخصائص التركيبية للخلايا التابعة النشطة جنبا إلى جنب مع استعادة السمات النسيجية الطبيعية للألياف العضلية. الخلاصة: الحقن الموضعى للبلازما الغنية بالصفائح الدموية ادى فى عضلة السمانة المصابة ادى الى التنشيط المبكر ،



